\title{
Challenges to antimicrobial susceptibility testing of plant- derived polyphenolic compounds
}

\author{
Marina Bubonja-Šonje ${ }^{1,2}$, Samira Kneževićc ${ }^{3}$, and Maja Abram ${ }^{1,2}$ \\ ${ }^{1}$ Department of Microbiology and Parasitology, Faculty of Medicine, University of Rijeka, Rijeka, Croatia \\ 2 Department of Clinical Microbiology, Clinical Hospital Centre Rijeka, Rijeka, Croatia \\ ${ }^{3}$ Clinic for Infectious Diseases, Clinical Hospital Centre Rijeka, Rijeka, Croatia
}

[Received in February 2020; Similarity Check in February 2020; Accepted in October 2020]

\begin{abstract}
As multidrug resistance gains momentum, the last two decades have seen an ever-growing interest in the antimicrobial properties of plant extracts and plant-derived compounds. Most of the focus is on polyphenols - a large and diverse group of phytochemicals with strong antibacterial activity. Testing methods provide reliable results as long as they follow standard procedures. However, methods and procedures used in antimicrobial susceptibility testing (AST) are often too diverse to allow comparison of results. The lack of uniformity and comparability is much owed to the absence of guidelines. The focus of this review is to give a critical overview of different methods used in the assessment of polyphenols antimicrobial efficacy and to highlight the importance of their standardisation.
\end{abstract}

KEY WORDS: antibiogram; AST; plant-derived compounds; polyphenols; standardisation

Over the past few decades, the search for antimicrobials derived from plants has accelerated, as bacterial resistance to antibiotics grows and new, clinically useful antibiotics fail to emerge. Research has focused on screening raw materials for new natural substances to replace synthetics. To protect themselves from microbial pathogens plants produce numerous secondary metabolites with antimicrobial properties, such as phenolic compounds, terpenoids, essential oils, alkaloids, lectins, and polypeptides (1). One of the largest and most widespread groups of plant chemicals with a diverse array of positive health effects are polyphenols. They exhibit significant antibacterial, antioxidant, anti-inflammatory, anticancer, and antihypertensive activity, largely attributed to interaction with cellular signalling pathways under normal and pathological conditions (2).

Polyphenols can be simple compounds with a single aromatic ring and low molecular weight or large and complex substances. Considering their chemical structure, they are generally divided in two groups: flavonoids and non-flavonoids. Flavonoids include flavones (luteolin), flavonols (quercetin), flavanones, flavanols (catechin, epicatechin), isoflavones, and anthocyanidins, while nonflavonoides include phenolic acids (benzoic and cinnamic acids), phenolic alcohols (tyrosol, hydroxytyrosol), stilbenes, and lignans (3). A number of phenolic compounds

Corresponding author: Marina Bubonja-Šonje, MD, $\mathrm{PhD}$, Department of Microbiology and Parasitology, Faculty of Medicine, University of Rijeka, Braće Branchetta 20, 51000 Rijeka, Croatia

E-mail:marina.bubonja@uniri.hr of plants used in traditional medicine (4) appear to have structures and modes of action that are different to those of antibiotics, which renders the risk of cross-resistance highly improbable makes them a potentially new class of antibiotic drug candidates or, more likely, resistance modifying agents in combination therapy with conventional antibiotics. Synergistic studies show promise against pathogens resistant to conventional antibiotics $(5,6)$. The last decade has seen growing evidence that plant-derived compounds can restore the clinical application of older antibiotics that are generally ineffective alone.

Even though their mechanisms of action are not fully clarified, polyphenols seem to damage bacterial cell membranes or interfere with the production of amino acids needed for bacterial growth (7). They also seem to modify bacterial resistance by inhibiting bacterial efflux pumps that expel antibiotics or by inhibiting enzymes that inactivate them $(8-15)$.

Bacterial susceptibility to conventional antibiotics is determined by a number of phenotypic and genotypic antimicrobial susceptibility testing (AST) methods available in clinical laboratories. The selection of optimal method is based on factors such as flexibility, practicality, automation, cost, accuracy, reliability, and reproducibility. However, with plant-derived compounds additional problems arise, because natural products are complex mixes of many compounds that may not act as expected in the test system. For this reason, only a few AST methods have found application in determining antibacterial activity of natural products. However, AST methods provide reliable results only when they follow standardised procedures. Otherwise, 
differences in experimental conditions can lead to large variations $(16,17)$. As the use of AST methods faces numerous challenges with polyphenols, the aim of this mini-review is to take a critical look at them and highlight the importance of their standardisation.

\section{FACTORS INFLUENCING AST METHODS}

\section{Solvents used for polyphenol extraction/solution and culture media}

Plant extracts are natural products, and their chemical composition varies. Screening crude plant extracts for desired bioactivity is one of the most important operations in the study of medicinal plants, and extraction is the first crucial step. The quality of plant extracts depends on plant material (part of the plant used fresh or dried), which may vary with climate, time of harvest, extraction method, solvent used, and (in)stability of constituents (18). This variation is also true for polyphenolic extracts. Extraction methods usually vary in length, $\mathrm{pH}$, temperature, particle size, and solvent-to-sample ratio, which also affects the quantity and quality of constituents obtained. This is why plant extraction methods should be standardised or harmonised to allow direct comparison of AST results.

Most phenolic compounds with antimicrobial activity are aromatic or saturated organic compounds and are usually obtained through initial ethanol extraction. Ethanol, however, can interfere with the bioassay. Its presence, even in very small amounts, can inhibit the growth of some microorganisms and affect test results. In concentrations $>2.5 \%$ it has toxic effects on some of food poisoning bacteria such as the Listeria and Staphylococcus genera $(19,20)$. Other solvents used are acetone, methanol, chloroform, water, and dimethyl sulphoxide (DMSO) (21-24). DMSO is frequently used because it dissolves both organic and inorganic compounds well. However, as an antioxidant it has also been reported to protect bacteria from death by antimicrobials in concentrations as low as $1 \%$ (25) and that its use as an extraction solvent should be reconsidered. Recent research has focused on new, sustainable, and environmentally safe extraction solvents such as supercritical fluids. For example, pure supercritical carbon dioxide is safe and may significantly enhance the efficiency of ethanol extraction (26).

To account for the possible influence of solvents on AST results testing should include not only plant extracts but also the antibacterial effect of the growth medium containing solvent (negative control). In addition, testing should include a standard antibiotic as positive control against which to compare the activity of the extract or polyphenolic compound.

With respect to growth media used for AST, MüllerHinton $(\mathrm{MH})$ broth/agar is a standard for testing the susceptibility of non-fastidious microorganisms to antibiotics. The use of another culture medium may lead to discrepancy in results such as the one observed in two studies of phenolic resveratrol antimicrobial activity (27, 28). Although both used the same reference bacterial strain, the minimum inhibitory concentration (MIC) of resveratrol was $0.1 \mathrm{mg} / \mathrm{mL}$ when the MH broth was used (27) and over $1 \mathrm{mg} / \mathrm{mL}$ when the Luria-Bertani broth was used (28). Variations in results are possible even with the recommended $\mathrm{MH}$ culture media due to differences in their activity and composition. Even standardised components and procedures require quality control (QC) to ensure reliable results. QC testing involves reference bacterial strains to yield MIC and zone diameter values within recommended ranges. Ahman et al. (29) evaluated 21 internationally available brands of MH dehydrated media using a standardised disc diffusion method only to find that the inhibition zone diameters for QC reference strains were outside the European Committee on Antimicrobial Susceptibility Testing (EUCAST) QC criteria (30) for all but six tested brands. Authors also reported major differences in cation content and $\mathrm{pH}$ between the agars. MH agars of poor quality can affect susceptibility tests to the point that they produce false positive or negative findings. Therefore, users should evaluate the performance of the media they use and confirm that QC criteria published by national and international standard organisations are met.

\section{AST guidelines and AST interpretative criteria (breakpoints)}

Each AST method requires specific testing conditions, including media, incubation time, and temperature. These procedures have specifically been designed for assessing the activity of conventional antimicrobial agents (such as antibiotics). Various authorities, such as EUCAST and Clinical and Laboratory Standards Institute (CLSI), provide AST guidelines for antibiotics (31-34), which promote development and standardisation of in vitro AST methods and work towards international consensus and harmonisation of clinical breakpoints and testing performance. These guidelines are also used for determining antimicrobial activity of plant-derived compounds, as they have no standards of their own. However, problems arise because antibiotics are generally hydrophilic, and all standardised AST methods have been optimised to this condition, whereas most polyphenols are lipophilic and are not fully soluble in water. This requires adjusting conventional EUCAST and CLSI reference methods for testing phenolic extracts.

Another problem arising from the use of AST guidelines developed for antibiotics is the absence of interpretation criteria (breakpoints) for susceptibility testing of plantderived substances. A breakpoint is the minimum drug concentration expected to be clinically effective against a microbe. It is used to describe bacterial isolates as susceptible, intermediate, or resistant. However, 
interpretation criteria for polyphenol ASTs are yet to be established by standard-setting bodies. In the meantime, different criteria are used. Many studies rely on MIC. MICs of conventional antibiotics typically range between 0.01 and $10 \mu \mathrm{g} / \mathrm{mL}$, whereas, plant compounds are routinely classified as antimicrobials if their MICs range between 100 and $1000 \mu \mathrm{g} / \mathrm{mL}$. However, claiming positive activity for excessively high plant compound concentrations is a common mistake, and Rios et al. (35) propose that the MIC for antimicrobial activity of a plant extract and isolated compound to be considered significant should be below $100 \mu \mathrm{g} / \mathrm{mL}$ and below $10 \mu \mathrm{g} / \mathrm{mL}$, respectively. Taguri et al. (36) propose the following cut-off MIC values of a pure compound/crude extract: $<400 \mu \mathrm{g} / \mathrm{mL}$ for strong antimicrobial effect, $400-800 \mu \mathrm{g} / \mathrm{mL}$ for moderate, and $>800 \mu \mathrm{g} / \mathrm{mL}$ for weak effect.

Bouarab-Chibane et al. (37), in turn, have taken a different approach, as they focus on polyphenol antimicrobial activity against food-spoiling bacteria. They propose polyphenol concentration of $1000 \mu \mathrm{g} / \mathrm{mL}$ for a breakpoint, as higher concentrations would have no practical use in the preservation of perishable foods. This parameter of antimicrobial activity is called bacterial load difference (BLD), and its significance (breakpoint) is set at $20 \%$ decrease in bacterial growth, which is achieved with $1000 \mu \mathrm{g} / \mathrm{mL}$ of polyphenols.

Besides the EUCAST and CLSI standards widely used by clinical microbiology laboratories, European Standard EN 1276:2009 (38) is used to evaluate plant extracts as food sanitisers and European Standard EN 12054:1997 (39) to evaluate plant extracts as hand antiseptics.

\section{Testing organisms and inocula}

Regardless of the chosen AST method, it is necessary to use well-defined, standardised microbial strains obtained from a recognised source such as American Type Culture Collection (ATCC) or National Collection of Type Cultures (NCTC). The use of reference strains with known susceptibility against existing antimicrobial agents enables internal quality control and makes it possible to calibrate the test and compare results between laboratories. The choice of test microorganisms depends on the specific purpose of research. Drug-sensitive Gram-positive and Gram-negative reference strains of common pathogenic species are preferable for AST screening.

Bacterial inoculum size is the most important variable in antibacterial activity testing. Greater inoculum size and longer incubation time can result in higher antimicrobial MIC, which only underlines the importance of controlled and standardised conditions for susceptibility testing. The EUCAST standard recommends inoculum of $5 \times 10^{5}$ colony forming units (CFU)/mL for broth microdilution method (31). This size can be assessed by counting viable colonies. To do that, $10 \mu \mathrm{L}$ of inoculum should be removed from a growth-control well or tube immediately after inoculation, diluted in $10 \mathrm{~mL}$ of saline, and $100 \mu \mathrm{L}$ spread onto a nonselective agar plate. After incubation, the number of colonies should be approximately $20-80$. For results to be valid it is important that the bacteria used in AST testing come in the log phase of growth from a fresh culture.

In addition to growth media, bacterial strains, and inoculum size, there are many other factors specific for each type of assay (volume of agar/broth, size of wells/paper discs, incubation conditions, endpoints determination), which will be discussed with particular AST method.

\section{COMMON IN VITRO AST METHODS}

Phenotypic AST methods are either qualitative (disc diffusion technique) or quantitative (dilution methods, E-test). Phenotypic assays rely on measuring growth inhibition, metabolism, and viability in the presence of antibacterial compounds. Some methods provide quick results, while others allow better understanding of antibacterial impact on the viability and cell damage of tested microorganism. Conventional phenotypic AST methods include agar disc diffusion, well diffusion, and agar or broth dilution.

\section{DIFFUSION METHODS}

\section{Agar disc diffusion assay}

In the disc diffusion test (Kirby-Bauer method) the suspension of a microorganism in saline to the density of a McFarland 0.5 turbidity standard, approximately corresponding to $1 \times 10^{8} \mathrm{CFU} / \mathrm{mL}$, is inoculated uniformly onto the surface of an agar plate. The density of the suspension is preferably measured with a photometric device that has been calibrated with a McFarland standard according to manufacturer's instructions. Alternatively, the density can be compared visually to a McFarland 0.5 and adjusted by addition of saline or more bacteria.

A paper disc containing a standard amount of an antimicrobial compound is applied to the surface of the plate, usually $\mathrm{MH}$ agar, and the substance is allowed to diffuse into the adjacent medium. Following incubation, bacterial growth appears on the plate. If the test isolate is susceptible to antimicrobial compound, a clear area of "no growth" will appear around the disc. This zone is referred to as the zone of inhibition. Its size will depend on the diffusion rate of the test solution and the degree of sensitivity of the microorganism. Strains resistant to an antimicrobial compound will reach the margin of disc. Inhibition zone diameter is therefore used to interpret inhibition, and standards for interpretation have been established for different antibiotics. The size of the inhibition zone in the disc diffusion test inversely correlates with MIC (40). 
Pre-prepared, quality-controlled antibiotic discs provide reproducible and reliable findings. Unfortunately, this is not the case with extract-soaked filter paper discs, as they are not commercially available. Instead, filter paper discs or sterile commercial blank discs (about $6 \mathrm{~mm}$ in diameter) are impregnated with $0.01-0.02 \mathrm{~mL}$ of diluted test solution and allowed to dry before placing on top of agar plates (41). Drying time varies from $2 \mathrm{~h}$ to overnight under laminar flow.

The disc diffusion method for screening of natural products for antimicrobial activity owes its popularity to simple use and low cost. However, it involves a number of critical steps, such as the choice of the medium, $\mathrm{pH}$, agar depth and moisture content, incubation conditions, and ensuring accurate inoculum density. The diameter of the inhibition zone may be affected by the solubility of the tested substance, diffusion range, and evaporation. Precipitation of water-insoluble substances in the disc will prevent any diffusion of antimicrobial substances into the agar. With mixtures of constituents with different diffusion rates, this may give unreliable results. In fact, no inhibition zone does not necessarily mean that the tested compound is ineffective, especially if we speak about less polar compounds, which diffuse more slowly in aqueous agar. It is therefore not surprising for phenolic compound AST to get inconsistent results. When a disc diffusion method is used, a correlation between a number of compound concentrations used and inhibition zone diameters needs to be established to consider it reliable $(17,42)$. The main disadvantage of the test, however, is that it is qualitative and does not distinguish between bactericidal and bacteriostatic effects. If used for antimicrobial screening, disc diffusion is better for low molecular weight compounds, whereas for high molecular weight compounds well diffusion is preferred (43).

\section{Agar well diffusion assay}

This method is frequently used for testing antimicrobial activity of plant-derived substances $(44,45)$. A bacterial isolate mixed with soft agar is poured onto a plate and cooled. Then wells are cut with a sterile borer (4-8 $\mathrm{mm}$ in diameter), and test substances placed into each well. After incubation, the plate is observed for clear zones of inhibition around the well. Another way is to spread inoculum suspension evenly on a solid agar plate and add antimicrobial substances into each well. Agar well diffusion seems to be more sensitive and convenient than the disc variant for testing cationic natural products, as they adsorb on the hydrophilic surface of the disc and not diffuse into the medium $(43,46)$.

Disc and well diffusion tests are qualitative, which means that they do not quantify the amount of the tested compound diffused in the agar medium. In view of known diffusion issues of non-polar compounds, both methods are a poor choice for AST of crude plant extracts, which often contain compounds with different polarities. Both have poor reproducibility and both often fail to yield a linear correlation between the inhibition zone diameter and antimicrobial concentration $(17,47)$. In such cases, antimicrobial activity should be determined with a quantitative dilution method.

\section{Bioautography}

Bioautography is a method of microbial detection relying on planar chromatography techniques. It can be used to test antimicrobial activity of plant extracts and pure compounds. Bioautography assays can be divided into three groups: (a) direct bioautography, (b) contact or agar diffusion bioautography, and (c) immersion or agar overlay bioautography. With direct bioautography microorganisms are grown directly on thin-layer chromatography (TLC) plates, which combine two uses: separation of analysed substances and antibacterial activity. Direct bioautography usually does not make use of agar gel. The plate is dipped in or sprayed with a seeded culture broth. Inhibition (bioautogram) is usually visualised thanks to tetrazolium salts converted to intensely coloured formazan by live aerobic and facultative anaerobic bacteria. For microaerophilic bacteria like Campylobacter spp. adenosine triphosphate (ATP) is a better choice, as it allows determination by bioluminescence (48).

Contact bioautography is a variant of agar diffusion often used to screen for antimicrobial activity of plant extracts (49-51). Unlike with other diffusion methods, the analyte diffuses to inoculated agar medium from the chromatographic layer. A sample to be analysed is first adsorbed on a TLC plate and then transferred from the TLC plate to inoculated agar surface (52).

Immersion (agar overlay) bioautography, combines direct and contact bioautography, as - unlike with contact bioautography - the seeded agar medium is applied onto the TLC plate (51).

Opinions about bioautography vary. Silva et al. (53) claim that it is practical, reproducible, and easy to perform. Rios et al. (54), in contrast, find bioautographic methods difficult to standardise, as there are many varying factors that affect results. Even so, bioautography has a number of advantages: it uses small amounts of a sample, it is suitable for evaluating complex lipophilic plant extracts, and it facilitates rapid, inexpensive, and easy evaluation (55).

Furthermore, bioautography provides information about antimicrobial activities of individual substances in a mixture. This is particularly true for TLC bioluminescence - a variant of direct bioautography used for rapid screening of complex mixtures (56). Complex mixtures are first separated by TLC. The TLC plate is then coated with bioluminescent bacteria to reveal antimicrobial activity as dark zones on a luminescent background. The advantage of this kind of separation combined with postchromatography bioassays is that it provides rapid and 
sensitive screening for individual antimicrobial compounds in various mixtures and can also be used for toxicity screening $(57,58)$.

\section{DILUTION METHODS}

In contrast to diffusion methods, dilution methods allow quantitation of MIC or minimal bactericidal concentration $(\mathrm{MBC})$. Their main disadvantage is that they require relatively large amounts of reagents and space.

\section{Agar dilution method}

A tested substance is mixed in various concentrations with the MH agar before solidification. An inoculum of 0.5 McFarland standard density is then diluted in broth to give $10^{7} \mathrm{CFU} / \mathrm{mL}$ (EUCAST/CLSI guidelines) $(31,32) .1-\mu \mathrm{L}$ bacterial suspensions will give a final inoculum of $10^{4} \mathrm{CFU} /$ spot. Inoculated agar plates are then incubated and growth estimated by the naked eye. This technique, however, is tedious, labour-intensive, and takes large amounts of tested compounds. To address this issue Golus et al. (59) have proposed agar microdilution for testing oily and coloured plant extracts. This method combines convenience and time/ cost effectiveness typical for microtitre methods with the advantages of the agar dilution of hydrophobic or coloured substances.

\section{Broth dilution method}

In the broth macrodilution tube assay serial dilutions of tested compounds prepared in a liquid medium (MH broth or water) are mixed with bacterial suspensions in a series of tubes. Broth microdilution assay (also known as microtitre/microwell plate method) uses microwell plates instead. Both assays show bacterial growth inhibition with various compounds by measuring turbidity after overnight incubation. Turbidity indicates how efficient specific concentrations of a tested compound are in inhibiting bacterial growth. The less turbid a sample is in each tube (well), the better the bacterial growth inhibition (efficiency). A growth medium without antimicrobial agents serves as control. At the same time as assays are performed, inoculum control has to be determined in a medium to ensure that an even and sufficient number of organisms is used in the test. Bacterial inoculum varies in this respect and can significantly affect the assessment of MIC. Inocula with cell counts lower than $5 \times 10^{5} \mathrm{CFU} / \mathrm{mL}$ can show false susceptibility.

$\mathrm{MBC}$ is determined by subculturing the dilution that has shown no growth in the MIC assay. The selection of methods depends on the nature of compounds such as solubility and molecular weight. Although the broth microdilution method is the best way to establish the real potency of a pure compound, this will greatly depend on the solubility of the tested compound. Water-insoluble compounds disperse poorly in a liquid growth medium and separate to oil and water phases. Furthermore, if plant extract solution is turbid and coloured, it will be difficult to determine the endpoints of bacterial growth. If turbidity is measured visually, bacterial growth may be underestimated. In addition, precipitation of insoluble substances of the plant extract to the bottom of the well can sometimes make difficult visual or electronic turbidity measurement. This problem has been solved with redox indicators such as tetrazolium salts (60) or resazurin (61), which change colour with bacterial growth. The wells showing bacterial growth become pink, whereas the wells showing no growth remain colourless or blue, depending on the indicator. This procedure is referred to as colorimetric MIC method. In other words, broth microdilution methods have endpoints that can be determined either as a measure of turbidity or of cell viability indicators. Adding the indicator also helps to semi-automate broth microdilution through image processing. Using standardised bacterial inoculum Sarker et al. (62) have proposed a modified resazurin method, which corrects dilution inaccuracies, to achieve more accuracy in MIC determination for natural products. Recently, Veiga et al. (63) proposed another improved and validated colorimetric microdilution assay with triphenyltetrazolium chloride (TTC) as an indicator precise enough to correlate absorbance with the concentration of viable microorganisms and determine not only MIC but also $50 \%$ and $90 \%$ inhibitory concentrations $\left(\mathrm{IC}_{50}\right.$ and $\mathrm{IC}_{90}$, respectively. TTC is a salt that changes colour from clear to pink as it is metabolised by viable bacteria. Even with these indicators, however, strongly coloured/opaque pose media make reading colour changes difficult. In such cases, samples from each well are plated on a solid medium and colonies counted.

Another recent improvement to the standard microdilution method was an attempt to annul the risk of a medium inhibiting antimicrobial activity and improve extract solubility at the same time $(64,65)$. In the first step, bacteria in the mid-logarithmic growth phase are washed twice by centrifugation, re-suspended in Tris buffer, and incubated with a polyphenol without a growth medium. After five hours of incubation, follows the second step, in which Tryptic soy broth is added and microplates incubated for another six to twelve hours, that is, until controls form clearly visible pellets. At this point, viable cells are counted to identify growth. Microplates are then left to incubate for a total of $48 \mathrm{~h}$ to confirm by visual inspection that bacterial growth has completely been inhibited. This two-step microdilution assay offers more precise evaluation of antimicrobial efficacy of the tested compound. In addition, this assay has an option to use DMSO to enhance the solubility of more hydrophobic compounds, which facilitates identification of cationic and less polar bioactive compounds, whereas with other compounds it yields similar activity readings as the standard assay (65).

Although both agar $(47,66-68)$ and broth dilution (69-72) methods are commonly used to assess antimicrobial 
activity of plant extracts and polyphenols, broth dilution produces the most consistent results (17).

The broth dilution method can also be used to assess the lethal effect of an antimicrobial agent and provide a dynamic picture of antimicrobial action and interaction over time (73).

\section{ANTIMICROBIAL SYNERGY TESTING}

\section{Time-kill assay}

Historically, the time-kill assay (TKA) has been used to evaluate bactericidal properties of a new drug or other product that is expected to have one by monitoring bacterial death caused by antimicrobials at a wide range of concentrations (0.5-4 × MIC) over time. Briefly, $10^{6} \mathrm{CFU} /$ $\mathrm{mL}$ of microorganisms are incubated with antimicrobials at $37^{\circ} \mathrm{C}$ for predetermined sampling time (e.g. 0, 2, 4, 8, 12 , and $24 \mathrm{~h}$ ). Aliquots (1 mL, or appropriate volume) are then removed from each test suspension, serially diluted ten times (tenfold dilution) in sterile saline, and plated on agar plates for colony count. The rate of bactericidal activity is presented as the time-kill curve or survival curve. Generally, a $3-\log _{10}$ drop in bacterial survival is considered the threshold for significant killing activity against a particular test microorganism.

TKA can also be used to evaluate synergistic effects of plant compound combinations $(69,74)$. Combination testing provides information about which antimicrobials can be combined to achieve optimal/maximal effect. In that respect, TKA and checkerboard assay are most commonly used to assess if there is synergy between phytochemicals and antibiotics $(75,76)$. Synergy is often defined as a $\geq 2 \log _{10}$ decrease in the bacterial count $(\mathrm{CFU} / \mathrm{mL})$ compared to the most active compound tested alone (77).

Critical factors that affect the outcome of TKA include the preparation of an actively growing inoculum and the use of quantitative subcultures from drug-containing tubes. When high drug concentrations ( $\geq 4 \times$ MIC) are tested, it is necessary to exclude the antibiotic carryover effect, which occurs when a tested compound transferred onto the agar plate with the subcultured aliquot is sufficient to inhibit the growth of viable microorganisms and results in a falsely low MBC. This phenomenon can be eliminated by widely streaking the transferred aliquot over at least one-half of an agar plate or by centrifugation and resuspension of the bacteria in antimicrobial-free media before plating.

\section{Checkerboard assay}

In checkerboard assay antibiotic is serially diluted along the abscissa and the plant compounds along the ordinate of microtitre plates. After inoculation and incubation, the plates are observed for bacterial growth and determination of MIC for a combination. Synergy is measured against the activity of individual components in a combination using the fractional inhibitory concentration (FIC) index, according to the following formula:

$$
\text { FICI }=\frac{\begin{array}{c}
\text { MICa in } \\
\text { combination }
\end{array}}{\text { MICa alone }}+\frac{\begin{array}{c}
\text { MICb in } \\
\text { combination }
\end{array}}{\text { MICb alone }}
$$

where $\mathrm{MICa}$ denotes the minimum inhibitory concentration of a plant extract and $\mathrm{MICb}$ of an antibiotic, if the synergy of the two is being evaluated.

The resulting index quantitatively denotes synergism if $\leq 0.5$, additive effect if $>0.5$ to $\leq 1$, or indifference if $>1$ (78). However, these indices are to be taken with reserve, as they involve one tube dilution variation and the possibility of reproducibility error. Due to inherent variability in MIC determination consequent inconsistent classification of the checkerboard assay results, Rand et al. (79) have proposed that a minimum of five replicates should be tested and $\geq 80 \%$ agreement achieved between them for the effect to be categorised.

In any case, synergy testing results obtained with checkerboard assay may differ from those obtained with TKA, as the checkerboard method yields results at one time point, whereas killing curves measure changes over time.

\section{MICROFLUIDIC AST METHODS}

Screening for biological activity is often limited by the availability of active compounds. This can be overcome by techniques requiring them in low quantities. Developed in the last decade, microfluidic-based culture methods allow monitoring bacterial growth in channels/chambers that take no more than $20 \mu \mathrm{L}$ of tested compounds (80). Li et al. (81) have recently demonstrated a promising adaptable microfluidic system that allows rapid phenotypic AST at the single-cell level. This miniaturisation made possible with new microfluidic technologies - described in detail in the review article of Schumacher et al. (82) - allows them to be integrated with an automatic device and therefore improve test speed and accuracy and achieve high throughput. Besides phenotypic, genotypic microfluidic ASTs have been developed for molecular detection of drug resistance to conventional antibiotics.

Recently, Parsley et al. (83) found significant differences in the bioactivity profiles of natural product peptides against E. coli between a microfluidic assay and a plate-based method. They suggested that the differences were owed to different bacterial growth conditions and different plastic materials involved in each assay and pointed out that microfluidic-based methods required significant optimisation to be reliably applied for AST.

Even so, microfluidics bring several advantages to AST over classical methods that use Petri dishes and multi-well plates, as they makes it possible to develop high throughput, real-time, low sample consumption assays. The downside is that such assays require expensive and specialised 
equipment and samples need several preparation steps before analysis (84).

\section{OTHER CONSIDERATIONS AND FUTURE NEEDS}

Each of the presented AST methods has advantages and disadvantages (Table 1) and none can be regarded as the universal "best" method. Instead, each is best suited to different needs.

New bioassays and protocols should be selective and precise enough to detect bioactive effects of small amounts of natural compounds against target pathogens. They should also take less time to identify potential antimicrobial candidates.

Many new AST methods are automated and well suited for routine testing of conventional antibiotics with conveniently prepared and formatted microdilution drug panels, instrumentation, and automated reading. Novel instruments turbidimetry/nephelometry instruments measuring bacterial growth reduce technical errors and lengthy preparation times. Automation also allows interlaboratory comparison and standardisation. However, these
AST systems are not adapted to testing natural bioactive compounds and several attempts have recently been made to develop an automated system suitable for AST of plant extracts $(85,86)$ or adapt the existing ones. Recently, for example, Bouarab-Chibane et al. (37) successfully applied a self-contained incubation and high-throughput, microplatebased microbial growth tracking system relying on optical density (Bioscreen $\mathrm{C}^{\mathrm{TM}}$ Automated Microbiology Growth Curve Analysis System, Growth Curves USA, Piscataway, NJ, USA) to quickly screen 35 polyphenols for activity against six pathogens.

In contrast, genetic methods, which are increasingly used for AST of antibiotics, have not yet been adapted for assessing microbial resistance to plant-derived substances, because molecular assays can only detect what is already known. As genetic profiling for resistance to natural compounds has not yet been made for all the bacteria, these essays are not commercially available for the time being. For us to develop tests for detecting resistance genes we first need to learn more about the mechanisms of activity of polyphenols and about the molecular basis of microbial resistance to them.

Another issue that deserves consideration is the applicability of in vitro testing in developing plant derived

Table 1 Overview of commonly used in vitro antimicrobial susceptibility testing methods

\begin{tabular}{|c|c|c|c|}
\hline Method & Advantages & Disadvantages & Reference \\
\hline $\begin{array}{l}\text { Agar disk } \\
\text { diffusion }\end{array}$ & $\begin{array}{l}\text { simplicity of performance, low cost, } \\
\text { flexibility, } \\
\text { no special equipment required, } \\
\text { suitable for lead identification }\end{array}$ & $\begin{array}{l}\text { qualitative assay, } \\
\text { poor level of reproducibility, } \\
\text { diffusion of antimicrobial substances } \\
\text { may be affected, applicable only to } \\
\text { fast-growing bacteria }\end{array}$ & $\begin{array}{l}(17,42,43 \\
46,47)\end{array}$ \\
\hline $\begin{array}{l}\text { Agar well } \\
\text { diffusion }\end{array}$ & $\begin{array}{l}\text { simplicity of performance, low cost, } \\
\text { more sensitive and more convenient than } \\
\text { the disc variant for testing of cationic } \\
\text { compounds }\end{array}$ & $\begin{array}{l}\text { qualitative assay, } \\
\text { poor level of reproducibility }\end{array}$ & $\begin{array}{l}(17,43 \\
46,47)\end{array}$ \\
\hline Bioautography & $\begin{array}{l}\text { simplicity of performance, } \\
\text { little amount of sample required, } \\
\text { rapid and inexpensive evaluation, } \\
\text { suitable for screening of antimicrobials in } \\
\text { mixtures }\end{array}$ & $\begin{array}{l}\text { qualitative assay, } \\
\text { difficult to standardise, } \\
\text { not suitable for synergy studies, } \\
\text { alteration of compounds during the } \\
\text { fractional phase }\end{array}$ & $(49-54)$ \\
\hline Agar dilution & $\begin{array}{l}\text { quantitative results, } \\
\text { a number of bacterial species may be } \\
\text { applied to a single dish }\end{array}$ & $\begin{array}{l}\text { laborious and time consuming method, } \\
\text { the large amount of reagents and space } \\
\text { required }\end{array}$ & $\begin{array}{l}(47,59 \\
66-68)\end{array}$ \\
\hline $\begin{array}{l}\text { Broth } \\
\text { microdilution }\end{array}$ & $\begin{array}{l}\text { quantitative results, } \\
\text { convenience and time/cost } \\
\text { effectiveness, } \\
\text { capacity to test opaque materials, } \\
\text { possible automation, } \\
\text { the most consistent results, } \\
\text { the killing effect can be assessed }\end{array}$ & $\begin{array}{l}\text { the possibility of errors in solution } \\
\text { preparation, } \\
\text { relatively high amount of space and } \\
\text { reagents required }\end{array}$ & $\begin{array}{l}(17,47,60- \\
64,69-71)\end{array}$ \\
\hline $\begin{array}{l}\text { Microfluidic } \\
\text { methods }\end{array}$ & $\begin{array}{l}\text { smaller volumes, } \\
\text { short run time, } \\
\text { higher sensitivity, } \\
\text { potential for high throughput }\end{array}$ & $\begin{array}{l}\text { specialised equipment needed, } \\
\text { high-cost }\end{array}$ & $(80-83)$ \\
\hline
\end{tabular}


substances as antimicrobial drugs. Namely, even though a plant compound may prove potent in vitro, it may have little biological activity in vivo if it does not reach the target tissues. Regardless of the testing method, in vitro measurement of antimicrobial activity does not address limited bioavailability for many of the larger polyphenols. Their activity may be affected by many host factors, such as biotransformation, $\mathrm{pH}$, and local tissue properties (e.g. abscess cavity, cerebrospinal fluid, or intracellular location). Although most polyphenols are absorbed to some extent, each phenolic compound is absorbed differently. Polyphenols get cleaved by stomach acid and undergo extensive enzymatic and chemical modification during digestion and absorption. In fact, they reach the target in very low concentrations, and this is the main obstacle to be addressed by further research. Smaller phenolic molecules are metabolised so quickly that only their metabolites can be found in the blood. Moreover these metabolites are generally rapidly eliminated from the plasma $(87,88)$. Knowledge about phenolic bioavailability has increased over the last years, and we now know that oral bioavailability of polyphenols is generally between 2 and $10 \%$ (89-94).

One promising solution to low oral bioavailability is the development of nanodelivery systems able to maintain the structural integrity of the bioactive molecules (95).

Furthermore, research should shift the focus to studying antimicrobial properties of phenolics in vivo (92-101). More animal and human experiments should be conducted in this field to establish general principles affecting their absorption in vivo.

Although naturally occurring polyphenols do not demonstrate toxic effects, any substance entered into the human body in excessive amounts can cause harm. The studies of polyphenols toxicity essential for the drug development process are also still lacking (102-105). Therefore, in any eventual uses of different polyphenols as antimicrobials, the safety aspects have to be taken into account as well.

To sum up, further research should focus on determining structure-function relationships, mechanisms of action, pharmacokinetic profiles, and interactions with antibiotics or other medicinal plants or compounds to better understand phenolic antimicrobial effects in vivo and optimise them through structural changes whether used alone or, more likely, as potentiators of other antibacterial agents.

\section{Conflicts of interest}

None to declare.

\section{REFERENCES}

1. Cowan MM. Plant products as antimicrobial agents. Clin Microbiol Rev 1999;12:564-82. PMCID: PMC88925

2. Vauzour D, Rodriguez-Mateos A, Corona G, Oruna-Concha MJ, Spencer JPE. Polyphenols and human health: prevention of disease and mechanisms of action. Nutrients 2010;2:110631. doi: $10.3390 /$ nu2 111106

3. Daglia M. Polyphenols as antimicrobial agents. Curr Opin Biotechnol 2012;23:174-81. doi: 10.1016/j. copbio.2011.08.007

4. Cushnie TP, Lamb AJ. Antimicrobial activity of flavonoids. Int J Antimicrob Agents 2005;26:343-56. doi: 10.1016/j. ijantimicag.2005.09.002

5. Barbieri R, Coppo E, Marchese A, Daglia M, SobarzoSánchez E, Nabavi SF, Nabavi SM. Phytochemicals for human disease: An update on plant-derived compounds antibacterial activity. Microbiol Res 2017;196:44-68. doi: 10.1016/j.micres.2016.12.003

6. Cheesman MJ, Ilanko A, Blonk B, Cock IE. Developing new antimicrobial therapies: Are synergistic combinations of plant extracts/compounds with conventional antibiotics the solution? Pharmacogn Rev 2017;11:57-72. doi: 10.4103/ phrev.phrev_21_17

7. Nohynek LJ, Alakomi HL, Kähkönen MP Heinonen M, Helander IM, Oksman-Caldentey KM, Puupponen-Pimiä RH. Berry phenolics: antimicrobial properties and mechanisms of action against severe human pathogens. Nutr Cancer 2006;54:18-32. doi: 10.1207/s15327914nc5401_4

8. Sudano Roccaro A, Blanco AR, Giuliano F, Rusciano D, Enea V. Epigallocatechin-gallate enhances the activity of tetracycline in staphylococci by inhibiting its efflux from bacterial cells. Antimicrob Agents Chemother 2004;48:196873. doi: 10.1128/AAC.48.6.1968-1973.2004

9. Stavri M, Piddock LJV, Gibbons S. Bacterial efflux pump inhibitors from natural sources. J Antimicrob Chemother 2007;59:1247-60. doi: 10.1093/jac/dk1460

10. Zhao W, Hu Z, Hara Y, Shimamura T. Inhibition of penicillinase by epigallocatechin gallate resulting in restoration of antibacterial activity of penicillin against penicillinase-producing Staphylococcus aureus. Antimicrob Agents Chemother 2002;46:2266-8. doi: 10.1128/ aac.46.7.2266-2268.2002

11. Holler JG, Christensen SB, Slotved HC, Rasmussen HB, Gúzman A, Olsen CE, Petersen B, Mølgaard P. Novel inhibitory activity of the Staphylococcus aureus NorA efflux pump by a kaempferol rhamnoside isolated from Persea lingue Nees. J Antimicrob Chemother 2012;67:1138-44. doi: 10.1093/jac/dks005

12. de Araujo RS, Barbosa-Filho JM, Scotti MT, Scotti L, da Cruz RM, Falcao-Silva Vdos S, de Siqueira-Júnior JP, Mendonça-Junior FJ. Modulation of drug resistance in Staphylococcus aureus with Coumarin derivatives. Scientifica (Cairo) 2016;2016:6894758. doi: $10.1155 / 2016 / 6894758$

13. Klančnik A, Šikić Pogačar M, Trošt K, Tušek Žnidarič M, Možetič Vodopivec B, Smole Možina S. Anti-Campylobacter activity of resveratrol and an extract from waste Pinot noir grape skins and seeds, and resistance of Camp. jejuni planktonic and biofilm cells, mediated via the CmeABC efflux pump. J Appl Microbiol 2017;122:65-77. doi: 10.1111/ jam. 13315

14. Sousa V, Luís Â, Oleastro M, Domingues F, Ferreira S. Polyphenols as resistance modulators in Arcobacter butzleri. Folia Microbiol (Praha) 2019;64:547-54. doi: 10.1007/ s12223-019-00678-3

15. Hwang D, Lim YH. Resveratrol controls Escherichia coli growth by inhibiting the AcrAB-TolC efflux pump. FEMS 
Microbiol Lett 2019;366(4):fnz030. doi: 10.1093/femsle/ fnz030

16. Bubonja M, Mesarić M, Miše A, Jakovac M, Abram M. Utjecaj različitih čimbenika na rezultate testiranja osjetljivosti bakterija disk difuzijskom metodom [Factors affecting the antimicrobial susceptibility testing of bacteria by disc diffusion method, in Croatian]. Med Fluminensis 2008;44:280-4.

17. King T, Dykes G, Kristianti R. Comparative evaluation of methods commonly used to determine antimicrobial susceptibility to plant extracts and phenolic compounds. J AOAC Int 2008;91:1423-9. doi: 10.1093/jaoac/91.6.1423

18. Garcia-Salas P, Morales-Soto A, Segura-Carretero A, Fernández-Gutiérrez A. Phenolic-compound-extraction systems for fruit and vegetable samples. Molecules 2010;15:8813-26. doi: 10.3390/molecules 15128813

19. Barker C, Park SF. Sensitization of Listeria monocytogenes to low $\mathrm{pH}$, organic acids, and osmotic stress by ethanol. Appl Environ Microbiol 2001;67:1594-600. doi: 10.1128/ AEM.67.4.1594-1600.2001

20. Chatterjee I, Somerville GA, Heilmann C, Sahl HG, Maurer HH, Herrmann M. Very low ethanol concentrations affect the viability and growth recovery in post-stationary-phase Staphylococcus aureus populations. Appl Environ Microbiol 2006;72:2627-36. doi: 10.1128/AEM.72.4.2627-2636.2006

21. Escribano-Bailon MT, Santos-Buelga C. Polyphenol extraction from foods. In: Santos-Buelga C, Williamson G, editors. Methods in polyphenol analysis. London: The Royal Society of Chemistry; 2003. p. 1-16.

22. Tambekar DH, Khante BS, Chandak BR, Titare AS, Boralkar SS, Aghadte SN. Screening of antibacterial potentials of some medicinal plants from Melghat Forest in India. Afr J Tradit Complement Altern Med 2009;6:228-32. doi: 10.4314/ ajtcam.v6i3.57158

23. Malik F, Hussain S, Mirza T, Hameed A, Ahmad S, Riaz H, Akhtar Shah P, Usmanghani K. Screening for antimicrobial activity of thirty-three medicinal plants used in the traditional system of medicine in Pakistan. J Med Plants Res 2011;5:3052-60.

24. Aires A. Phenolics in foods: extraction, analysis and measurements. In: Soto-Hernandez M, Palma-Tenango M, Garcia-Mateos R, editors. Phenolic compounds - natural sources, importance and applications. IntechOpen; 2017. p. 61-88. doi: $10.5772 / 66889$

25. Mi H, Wang D, Xue Y, Zhang Z, Niu J, Hong Y, Drlica K, Zhao X. Dimethyl sulfoxide protects Escherichia coli from rapid antimicrobial-mediated killing. Antimicrob Agents Chemother 2016;60:5054-8. doi: 10.1128/AAC.03003-15

26. Tyśkiewicz K, Konkol M, Rój E. The application of supercritical fluid extraction in phenolic compounds isolation from natural plant materials. Molecules 2018;23(10):2625. doi: 10.3390/molecules23102625

27. Paulo L, Ferreira S, Gallardo E, Queiroz JA, Domingues F. Antimicrobial activity and effects of resveratrol on human pathogenic bacteria. World J Microbiol Biotechnol 2010;26:1533-8. doi: 10.1007/s11274-010-0325-7

28. Jung CM, Heinze TM, Schnackenberg LK, Mullis LB, Elkins SA, Elkins CA, Steele RS, Sutherland JB. Interaction of dietary resveratrol with animal-associated bacteria. FEMS Microbiol Lett 2009;297:266-73. doi: 10.1111/j.1574-6968.2009.01691.x
29. Åhman J, Matuschek E, Kahlmeter G. EUCAST evaluation of 21 brands of Mueller-Hinton dehydrated media for disk diffusion testing. Clin Microbiol Infect 2020;26:1412.e1-5. doi: 10.1016/j.cmi.2020.01.018

30. European Committee on Antimicrobial Susceptibility Testing. Routine and extended internal quality control for MIC determination and disk diffusion as recommended by EUCAST version 10.0 [displayed 29 October 2020]. Available at https://www.eucast.org/fileadmin/src/media/ PDFs/EUCAST_files/QC/v_10.0_EUCAST_QC_tables routine_and_extended_QC.pdf

31. European Committee on Antimicrobial Susceptibility Testing (EUCAST) [displayed 20 December 2019]. Available at https://www.eucast.org/

32. Clinical and Laboratory Standards Institute (CLSI). Performance standards for antimicrobial susceptibility testing. $2^{\text {th }}$ ed. CLSI supplement M100. Wayne (PA): CLSI; 2019.

33. Clinical and Laboratory Standards Institute (CLSI). Performance standards for antimicrobial disk susceptibility tests; approved standard. $13^{\text {th }}$ ed. CLSI standard M02. Wayne (PA):CLSI; 2018.

34. Clinical and Laboratory Standards Institute (CLSI). Methods for dilution antimicrobial susceptibility tests for bacteria that grow aerobically; approved standard. $11^{\text {th }}$ ed. CLSI standard M07. Wayne (PA): CLSI; 2018.

35. Ríos JL, Recio MC. Medicinal plants and antimicrobial activity. J Ethnopharmacol 2005;100:80-4. doi: 10.1016/j. jep.2005.04.025

36. Taguri T, Tanaka T, Kouno I. Antibacterial spectrum of plant polyphenols and extracts depending upon hydroxyphenyl structure. Biol Pharm Bull 2006;29:2226-35. doi: 10.1248/ bpb. 29.2226

37. Bouarab-Chibane L, Forquet V, Lantéri P, Clément Y, Léonard-Akkari L, Oulahal N, Degraeve P, Bordes C. Antibacterial properties of polyphenols: characterization and QSAR (Quantitative Structure-Activity Relationship) models. Front Microbiol 2019;10:829. doi: 10.3389/ fmicb.2019.00829

38. European Committee for Standardization. European standard EN 1276:2009. Chemical disinfectants and antiseptics Quantitative suspension test for evaluation of bactericidal activity of chemical disinfectants and antiseptics used in food, industrial, domestic and institutional areas. Test method and requirements (phase 2, step 1).

39. European Committee for Standardization. European standard EN 1500:1997. Chemical disinfectants and antiseptics. Hygienic handrub. Test method and requirements (phase 2/ step 2) [displayed 20 December 2019]. Available at https:// www.sis.se/api/document/preview/21676/

40. Matuschek E, Brown DF, Kahlmeter G. Development of the EUCAST disk diffusion antimicrobial susceptibility testing method and its implementation in routine microbiology laboratories. Clin Microbiol Infect 2014;20:0255-66. doi: 10.1111/1469-0691.12373

41. Balouiri M, Sadiki M, Ibnsouda SK. Methods for in vitro evaluating antimicrobial activity: A review. J Pharm Anal 2016;6:71-9. doi: 10.1016/j.jpha.2015.11.005

42. Bubonja-Sonje M, Giacometti J, Abram M. Antioxidant and antilisterial activity of olive oil, cocoa and rosemary extract polyphenols. Food Chem 2011;127:1821-7. doi: 10.1016/j. foodchem.2011.02.071 
43. Valgas C, de Souza SM, Smânia E, Smânia A. Screening methods to determine antibacterial activity of natural products. Braz J Microbiol 2007;38:369-80. doi: 10.1590/ S1517-83822007000200034

44. Dahiya P, Purkayastha S. Phytochemical screening and antimicrobial activity of some medicinal plants against multidrug resistant bacteria from clinical isolates. Indian J Pharm Sci 2012;74:443-50. doi: 10.4103/0250-474X.108420

45. Ginovyan M, Petrosyan M, Trchounian A. Antimicrobial activity of some plant materials used in Armenian traditional medicine. BMC Complement Altern Med 2017;17:50. doi: 10.1186/s12906-017-1573-y

46. Essawi T, Srour M. Screening of some Palestinian medicinal plants for antibacterial activity. J Ethnopharmacol 2000;70:343-9. doi: 10.1016/s0378-8741(99)00187-7

47. Klancnik A, Piskernik S, Jersek B, Mozina SS. Evaluation of diffusion and dilution methods to determine the antibacterial activity of plant extracts. J Microbiol Methods 2010;81:121-6. doi: 10.1016/j.mimet.2010.02.004

48. Hara KY, Mori H. An efficient method for quantitative determination of cellular ATP synthetic activity. J Biomol Screen 2006;11:310-7. doi: 10.1177/1087057105285112

49. Horváth G, Acs K, Kocsis B. TLC-direct bioautography for determination of antibacterial activity of Artemisia adamsii essential oil. J AOAC Int 2013;96:1209-13. doi: 10.5740/ jaoacint.sgehorvath

50. Nostro A, Germanò MP, D'angelo V, Marino A, Cannatelli MA. Extraction methods and bioautography for evaluation of medicinal plant antimicrobial activity. Lett Appl Microbiol 2000;30:379-84. doi: 10.1046/j.1472-765x.2000.00731.x

51. Choma IM, Grzelak EM. Bioautography detection in thinlayer chromatography. J Chromatogr A 2011;1218:2684-91. doi: 10.1016/j.chroma.2010.12.069

52. Hamburger MO, Cordell GA. A Direct bioautographic TLC assay for compounds possessing antibacterial activity. J Nat Prod 1987;50:19-22. doi: 10.1021/np50049a003

53. Silva MT, Simas SM, Batista TG, Cardarelli P, Tomassini TC. Studies on antimicrobial activity, in vitro, of Physalis angulata L. (Solanaceae) fraction and physalin B bringing out the importance of assay determination. Mem Inst Oswaldo Cruz 2005;100:779-82. doi: 10.1590/s007402762005000700018

54. Rios J, Recio M, Villar A. Screening methods for natural products with antimicrobial activity: a review of the literature. J Ethnopharmacol 1988;23:127-49. doi: 10.1016/03788741(88)90001-3

55. Shahverdi AR, Abdolpour F, Monsef-Esfahani HR, Farsam HA. A TLC bioautographic assay for the detection of nitrofurantoin resistance reversal compound. J Chromatogr B 2007;850:528-30. doi:10.1016/j.jchromb.2006.11.011

56. Verbitski SM, Gourdin GT, Ikenouye LM, McChesney JD. Rapid screening of complex mixtures by thin layer chromatography-bioluminescence. Am Biotechnol Lab 2006;24:40-1.

57. Polatoglu K, Demirci F, Demirci B, Gören N, Can Baser KH. Antimicrobial activity and essential oil composition of a new T. argyrophyllum (C. Koch) Tvzel var. argyrophyllum chemotype. J Oleo Sci 2010;59:307-13. doi: 10.5650/ jos.59.307

58. Horváth G, Kocsis B, Lemberkovics E, Böszörményi A, Ott P, Móricz A. Detection of antibacterial activity of essential oil components by TLC-bioautography using luminescent bacteria. J Planar Chromatogr 2013;26:114-8. doi: 10.1556/ JPC.26.2013.2.2

59. Golus J, Sawicki R, Widelski J, Ginalska G. The agar microdilution method - a new method for antimicrobial susceptibility testing for essential oils and plant extracts. J Appl Microbiol 2016;121:1291-9. doi: 10.1111/jam.13253

60. Eloff JN. A sensitive and quick microplate method to determine the minimal inhibitory concentration of plant extracts for bacteria. Planta Med 1998;64:711-3. doi: 10.1055/s-2006-957563

61. Mann CM, Markham JL. A new method for determining the minimum inhibitory concentration of essential oils. J Appl Microbiol 1998;84:538-44. do i : 10.1046/j.1365-2672.1998.00379.x

62. Sarker SD, Nahar L, Kumarasamy Y. Microtitre plate-based antibacterial assay incorporating resazurin as an indicator of cell growth, and its application in the in vitro antibacterial screening of phytochemicals. Methods 2007;42:321-4. doi: 10.1016/j.ymeth.2007.01.006

63. Veiga A, Toledo MDGT, Rossa LS, Mengarda M, Stofella NCF, Oliveira LJ, Gonçalves AG, Murakami FS. Colorimetric microdilution assay: Validation of a standard method for determination of MIC, IC $50 \%$, and IC $90 \%$ of antimicrobial compounds. J Microbiol Methods 2019;162:50-61. doi: 10.1016/j.mimet.2019.05.003

64. Strömstedt AA, Park S, Burman R, Göransson U. Bactericidal activity of cyclotides where phosphatidylethanolamine-lipid selectivity determines antimicrobial spectra. Biochim Biophys Acta Biomembr 2017;1859:1986-2000. doi: 10.1016/j.bbamem.2017.06.018

65. Mohotti S, Rajendran S, Muhammad T, Strömstedt AA, Adhikari A, Burman R, de Silva ED, Göransson U, Hettiarachchi CM, Gunasekera S. Screening for bioactive secondary metabolites in Sri Lankan medicinal plants by microfractionation and targeted isolation of antimicrobial flavonoids from Derris scandens. J Ethnopharmacol 2020;246:112158. doi: 10.1016/j.jep.2019.112158

66. Hammer KA, Carson CF, Riley TV. Antimicrobial activity of essential oils and other plant extracts. J Appl Microbiol 1999;86:985-90. doi: 10.1046/j.1365-2672.1999.00780.x

67. Ertürk Ö. Antibacterial and antifungal activity of ethanolic extracts from eleven spice plants. Biologia 2006;61:275-8. doi: 10.2478/s11756-006-0050-8

68. Assam JP, Dzoyem JP, Pieme CA, Penlap VB. In vitro antibacterial activity and acute toxicity studies of aqueousmethanol extract of Sida rhombifolia Linn. (Malvaceae). BMC Complement Altern Med 2010;10:40. doi: 10.1186/1472-6882-10-40

69. Koochak H, Seyyednejad SM, Motamedi H. Preliminary study on the antibacterial activity of some medicinal plants of Khuzestan (Iran). Asian Pac J Trop Med 2010;3:180-4. doi: 10.1016/S1995-7645(10)60004-1

70. Konaté K, Hilou A, Mavoungou JF, Lepengué AN, Souza A, Barro N, Datté JY, M'batchi B, Nacoulma OG. Antimicrobial activity of polyphenol-rich fractions from Sida alba L. (Malvaceae) against co-trimoxazol-resistant bacteria strains. Ann Clin Microbiol Antimicrob 2012;11:5. doi: 10.1186/14760711-11-5

71. Nsor-Atindana J, Zhong F, Mothibe KJ, Bangoura ML, Lagnika C. Quantification of total polyphenolic content and antimicrobial activity of cocoa (Theobroma cacao L.) bean 
shells. Pak J Nutr 2012;11:574-9. doi: 10.3923/ pjn.2012.672.677

72. Farhadi F, Khameneh B, Iranshahi M, Iranshahy M. Antibacterial activity of flavonoids and their structureactivity relationship: An update review. Phytother Res 2019;33:13-40. doi: 10.1002/ptr.6208

73. May J, Chan CH, King A, Williams L, French GL. Time-kill studies of tea tree oils on clinical isolates. J Antimicrob Chemother 2000;45:39-43. doi: 10.1093/jac/45.5.639

74. Jayaraman P, Sakharkar MK, Lim CS, Tang TH, Sakharkar KR. Activity and interactions of antibiotic and phytochemical combinations against Pseudomonas aeruginosa in vitro. Int J Biol Sci 2010;6:556-8. doi: 10.7150/ijbs.6.556

75. Sopirala MM, Mangino JE, Gebreyes WA, Biller B, Bannerman T, Balada-Llasat JM, Pancholi P. Synergy testing by Etest, microdilution checkerboard, and time-kill methods for pan-drug-resistant Acinetobacter baumannii. Antimicrob Agents Chemother 2010;54:4678-83. doi: 10.1128/ AAC.00497-10

76. Betts JW, Hornsey M, Higgins PG, Lucassen K, Wille J, Salguero FJ, Seifert H, La Ragione RM. Restoring the activity of the antibiotic aztreonam using the polyphenol epigallocatechin gallate (EGCG) against multidrug-resistant clinical isolates of Pseudomonas aeruginosa. J Med Microbiol 2019;68:1552-9. doi: 10.1099/jmm.0.001060

77. Stapleton PD, Shah S, Anderson JC, Hara Y, Hamilton-Miller $\mathrm{JM}$, Taylor PW. Modulation of $\beta$-lactam resistance in Staphylococcus aureus by catechins and gallates. Int J Antimicrob Agents 2004;23:462-7. doi: 10.1016/j. ijantimicag.2003.09.027

78. Pillai SK, Moellering RC, Eliopoulos GM. Antimicrobial combinations. In: Lorian V, editor. Antibiotics in laboratory medicine. Philadelphia: Lippincott Williams and Wilkins; 2005. p. 365-440.

79. Rand KH, Houck HJ, Brown P, Bennett D. Reproducibility of the microdilution checkerboard method for antibiotic synergy. Antimicrob Agents Chemother 1993;37:613-5. doi: 10.1128/aac.37.3.613

80. Mattupalli C, Spraker JE, Berthier E, Charkowski AO, Keller NP, Shepherd RW. A microfluidic assay for identifying differential responses of plant and human fungal pathogens to tobacco phylloplanins. Plant Health Prog 2014;15:130-4. doi: 10.1094/PHP-RS-14-0009

81. Li H, Torab P, Mach KE, Surrette C, England MR, Craft DW, Thomas NJ, Liao JC, Puleo C, Wong PK. Adaptable microfluidic system for single-cell pathogen classification and antimicrobial susceptibility testing. Proc Natl Acad Sci U S A 2019;116:10270-9. doi: 10.1073/pnas.1819569116

82. Schumacher A, Vranken T, Malhotra A, Arts AJJC, Habibovic P. In vitro antimicrobial susceptibility testing methods: agar dilution to 3D tissue-engineered models. Eur J Clin Microbiol Infect Dis 2018;37:187-208. doi: 10.1007/s10096-017-30892

83. Parsley NC, Smythers AL, Hicks LM. Implementation of Microfluidics for Antimicrobial Susceptibility Assays: Issues and Optimization Requirements. Front Cell Infect Microbiol 2020:17;10:547177. doi: 10.3389/fcimb.2020.547177

84. Murray C, Adeyiga O, Owsley K, Di Carlo D. Research highlights: microfluidic analysis of antimicrobial susceptibility. Lab Chip 2015;15:1226-9. doi: 10.1039/ c5lc90017d
85. Kavak DD, Altıok E, Bayraktar O, Ülkü S. Pistacia terebinthus extract: As a potential antioxidant, antimicrobial and possible $\beta$-glucuronidase inhibitor. J Mol Catal B Enzym 2010;64,167-71. doi: 10.1016/j.molcatb.2010.01.029

86. Kreander K, Riihimaki L, Vuorela P. Antimicrobial susceptibility studies with Varioskan [displayed 30 January 2020]. Available at https://www.ld.ru/w/implen/Varioskan_ bacterial_growth_assay.pdf

87. D'Archivio M, Filesi C, Di Benedetto R, Gargiulo R, Giovannini C, Masella R. Polyphenols, dietary sources and bioavailability. Ann Ist Super Sanita 2007;43:348-61. PMID: 18209268

88. D'Archivio M, Filesi C, Varì R, Scazzocchio B. Bioavailability of the polyphenols: status and controversies. Int J Mol Sci 2010;11:1321-42. doi: 10.3390/ijms11041321

89. Manach C, Williamson G, Morand C, Scalbert A. Bioavailability and bioefficacy of polyphenols in humans. I. Review of 97 bioavailability studies. Am J Clin Nutr 2005;81(Suppl 1):230S-42S. doi: 10.1093/ajcn/81.1.230S

90. Williamson G, Manach C. Bioavailability and bioefficacy of polyphenols in humans. II. Review of 93 intervention studies. Am J Clin Nutr 2005;81(Suppl 1):243S-55S. doi: 10.1093/ ajcn/81.1.243S

91. Wenzel E, Somoza V. Metabolism and bioavailability of trans-resveratrol. Mol Nutr Food Res 2005;49:472-81. doi: $10.1002 / \mathrm{mnfr} .200500010$

92. Lee MH, Kwon HA, Kwon DY, Park H, Sohn DH, Kim YC, Eo SK, Kang HY, Kim SW, Lee JH. Antibacterial activity of medicinal herb extracts against Salmonella. Int J Food Microbiol 2006;111:270-5. doi: 10.1016/j. ijfoodmicro.2006.06.004

93. Choi JG, Kang OH, Lee YS, Chae HS, Oh YC, Brice OO, Kim MS, Sohn DH, Kim HS, Park H, Shin DW, Rho JR, Kwon DY. In vitro and in vivo antibacterial activity of Punica granatum peel ethanol extract against Salmonella. Evid Based Complement Alternat Med 2011;2011:690518. doi: 10.1093/ecam/nep105

94. Shahidi F, Peng H. Bioaccessibility and bioavailability of phenolic compounds. J Food Bioact 2018;4:11-68. doi: 10.31665/JFB.2018.4162

95. Conte R, Calarco A, Napoletano A, Valentino A, Margarucci S, Di Cristo F, Di Salle A, Peluso G. Polyphenols nanoencapsulation for therapeutic applications. J Biomol Res Ther 2016;5:2. doi: 10.4172/2167-7956.1000139

96. $\mathrm{Hu} \mathrm{M}$. Commentary: bioavailability of flavonoids and polyphenols: call to arms. Mol Pharm 2007;4:803-6. doi: $10.1021 / \mathrm{mp} 7001363$

97. Sakanaka S, Shimura N, Aizawa M, Kim M, Yamamoto T. Preventive effect of green tea polyphenols against dental caries in conventional rats. Biosci Biotechnol Biochem 1992;56:592-4. doi: 10.1271/bbb.56.592

98. Toda M, Okubo S, Ikigai H, Suzuki T, Suzuki Y, Hara Y, Shimamura $\mathrm{T}$. The protective activity of tea catechins against experimental infection by Vibrio cholerae O1. Microbiol Immunol 1992;36:999-1001. doi: 10.1111/j.1348-0421.1992. tb02103.x

99. Vijaya K, Ananthan S. Therapeutic efficacy of medicinal plants against experimentally induced shigellosos in guinea pigs. Indian J Pharm Sci 1996;58:191-3.

100. Dastidar SG, Manna A, Kumar KA, Mazumdar K, Dutta NK, Chakrabarty AN, Motohashi N, Shirataki Y. Studies on the antibacterial potentiality of isoflavones. Int J Antimicrob 
Agents 2004;23:99-102. doi: $10.1016 / \mathrm{j}$. ijantimicag.2003.06.003

101. Bhattacharya D, Sinha R, Mukherjee P, Howlader DR, Nag D, Sarkar S, Koley H, Withey JH, Gachhui R. Anti-virulence activity of polyphenolic fraction isolated from Kombucha against Vibrio cholerae. Microb Pathog 2019;140:103927. doi: 10.1016/j.micpath.2019.103927.

102. Soni MG, Burdock GA, Christian MS, Bitler CM, Crea R. Safety assessment of aqueous olive pulp extract as an antioxidant or antimicrobial agent in foods. Food Chem Toxicol 2006;44:903-15. doi: 10.1016/j.fct.2006.01.008
103. Akroum S, Bendjeddou D, Satta D, Lalaoui K. Antibacterial activity and acute toxicity effect of flavonoids extracted from Mentha longifolia. Am Euras J Sci Res 2009;2:93-6.

104. Ruiz MJ, Fernández M, Picó Y, Mañes J, Asensi M, Carda C, Asensio G, Estrela JM. Dietary administration of high doses of pterostilbene and quercetin to mice is not toxic. $\mathrm{J}$ Agric Food Chem 2009;57:3180-6. doi: 10.1021/jf803579e

105. Boncler M, Golanski J, Lukasiak M, Redzynia M, Dastych $\mathrm{J}$, Watala C. A new approach for the assessment of the toxicity of polyphenol-rich compounds with the use of high content screening analysis. PLoS One 2017;12(6):e0180022. doi: 10.1371/journal.pone.0180022

\section{Izazovi određivanja antimikrobnog učinka polifenola}

Istraživanje antimikrobnih učinaka biljnih ekstrakata i spojeva u proteklih nekoliko desetljeća zaokuplja interes brojnih znanstvenika zbog sve veće otpornosti bakterija na antibiotike. Najčešći i najviše proučavani sekundarni biljni metaboliti su polifenoli - brojna i raznolika skupina fitokemikalija s dokazanim antibakterijskim djelovanjem. Međutim, istraživači koji proučavaju antimikrobni učinak prirodnih spojeva biljnoga podrijetla susreću se s brojnim preprekama, koje je potrebno prepoznati i izbjeći. Na rezultate ispitivanja antimikrobne osjetljivosti mogu utjecati brojni čimbenici, a izbor odgovarajuće metode ispitivanja od presudnog je značaja. Nepostojanje postupnika/smjernica za testiranje antimikrobnog učinka bioaktivnih prirodnih spojeva uvelike utječe na ujednačenost, analizu i usporedbu brojnih objavljenih rezultata. U načelu, samo primjena standardiziranih metoda osigurava dobivanje pouzdanih rezultata. Cilj je ovoga preglednog rada sustavno i kritički prikazati različite metode koje se koriste za ispitivanje antimikrobnog učinka polifenola te istaknuti potrebu za njihovom standardizacijom.

KLJUČNE RIJEČI: antibiogram; ispitivanje antimikrobne osjetljivosti; prirodni spojevi biljnoga podrijetla; standardizacija 